Marquette University

e-Publications@Marquette

4-1-2011

Utilization of Employment Tax Credits: An Analysis of the Empowerment Zone Wage Tax Credit

Andrew Hanson

Marquette University, andrew.r.hanson@marquette.edu

Accepted version. Public Budgeting and Finance, Vol. 31, No. 1 (Spring 2011): 23-36. DOI. (C) 2011 John Wiley \& Sons (Public Financial Publications, Inc.). Used with permission. 


\title{
Utilization of Employment Tax Credits: An Analysis of the Empowerment Zone Wage Tax Credit
}

\author{
Published in Journal of Public Budgeting and Finance, Vol. 31, No. 1 Spring 2011
}

\begin{abstract}
:
This paper provides estimates of utilization for the Empowerment Zone (EZ) wage tax credit, a subsidy claimed by employers who operate in and hire residents of federally designated areas experiencing economic distress. The EZ credit is currently the largest employer-based wage tax credit in the federal tax code in terms of dollars claimed, with almost \$250 million claimed in 2002. I show that about 6.4 percent (and at least 3.5 percent) of the working age population was claimed under the EZ wage credit in 1999. In addition, I estimate that 24.2 percent (and at least 13.1 percent) of those employed inside of the target area were claimed for the credit. I create these national estimates of use with information on credit dollars claimed from the IRS and population data on the eligible population from the Census. These measures of tax credit use are an alternative to the use rate of firms that are presented in the existing literature, and reveal how effective the credit is at reaching residents of the target area.
\end{abstract}

JEL Classification: H25; H53; H43; R5; J38

Keywords: tax credits; urban redevelopment; utilization

I would like to thank Stacy Dickert-Conlin for guidance and advice throughout this project. I would also like to thank Leslie Papke, Don Bruce, Katie Fitzpatrick, and Sarah Hamersma for comments on an earlier draft. All errors are my own. 


\section{Introduction}

The federal tax system has numerous tax credits available to employers willing to hire various types of targeted employees. Typically, tax credits are available for employing current or former public assistance recipients or individuals with poor workplace attachments such as exconvicts. Since the start of the Empowerment Zone (EZ) program in 1995 the federal government has offered a generous tax credit to offset the wages paid to residents of impoverished inner city and rural areas. This relatively new form of targeting a wage tax credit is based on the residence of the employee and the location of the firm rather than on personal circumstances or history.

The EZ wage tax credit is currently the largest employer-based wage tax credit in terms of dollars and number of filers. Not only is the program large for it's type, but it has been growing steadily since its inception. The dollar amount of EZ tax credits claimed increased twelve fold in the first seven years of the program, from 1995 to 2002, while the number of filers increased by a factor of thirty-eight.

In addition to targeting recipients based on location, the EZ is different than most wage tax credits in that it does not require certification on the part of employees. The requirement to claim the credit is entirely based on geographic location of the firm and employee and does not distinguish between groups that traditionally receive government assistance (there is no means test or categorical requirement) and other residents living in the designated areas. The absence of a categorical requirement and employee certification makes the EZ wage tax credit unique from other tax credits that are claimed by employers because it eliminates the potential disincentive effects that can occur from employee stigma. 
In addition to the six original designations in 1995, 29 new EZs have been created since 1997. Despite the growing popularity of this place-based tax incentive, there is an incomplete understanding of the extent to which these credits are used by the targeted population. Much of the work that has been done focuses on the number and type of firms claiming these tax credits rather than the eligible population of employees. Understanding utilization among the eligible population is paramount to determining whether the EZ program is reaching the targeted population. This paper will examine the use of the credit by the eligible population, as opposed to the participation rate of firms claiming the credit.

The remainder of the paper starts by giving a description of the EZ program and discussing the previous literature. After reviewing the literature I outline my methodology for finding a national use rate for the EZ wage credit and give estimates based on data from the IRS and Census. The final sections of the paper discuss the findings and conclude.

\section{Description of EZ Program and Previous Literature}

The goal for the EZ program as stated by Senator Rick Santorum and Congressman J.C. Watts, Jr. in an April 29, 2002 joint letter to President George W. Bush is:

“... to create an environment that enables distressed urban and rural communities to have hope for the future through economic and social renewal. Our belief is that when private industry flourishes in these communities, it directly, and positively, impacts peoples' lives.” (HUD webpage: http://www.hud.gov/offices/cpd/economicdevelopment/programs/rc/index.cfm)

The Omnibus Budget Reconciliation Act of 1993 (OBRA 1993, P.L. 103-66) established the Empowerment Zone program. Employers were allowed to claim the EZ wage tax credit starting with 1995 tax returns for hiring residents of and operating within six inner-city (parts of Atlanta, Baltimore, Chicago, Detroit, Philadelphia/Camden, New York) and three rural (Kentucky Highlands, Mississippi Delta, and the Rio Grande Valley in Texas) areas. In addition to the nine 
original EZs, starting in 1999 the wage credit could also be claimed for employees who live in parts of the District of Columbia (IRS, 1998) and beginning in 2000 for parts of Cleveland and Los Angeles (HUD Q\&A).

Parts of these areas (divided up at the census tract ${ }^{1}$ level) were granted EZ status after being considered from a field of nominees (nominations were submitted by state and local governments). Nominations were considered for areas where at least 20 percent of the population was living in poverty and 6.3 percent were unemployed (GAO, 2004). Over 500 nominations were received (CRS, 2002) with the final designation of EZ status being determined by the Secretaries of the Department of Housing and Urban Development and the Department of Agriculture. $^{2}$

The EZ wage credit is one part of a package of assistance available to employers locating within the designated zones. The following incentives are also offered to employers in the zone: immediate expensing of qualified property; postponement of reported gain from the sale of qualified assets; increased exclusion of gains from the sale of small business stock; and state and local governments are permitted to issue tax exempt bonds to finance the purchase of property for EZ businesses. These incentives are accompanied by a one time allocation of \$100 million for urban and \$40 million for rural EZs in Social Service Block Grant funds. ${ }^{3}$

\footnotetext{
${ }^{1}$ The Census Bureau defines census tracts as statistical subdivisions of counties. Tracts average 4,000 inhabitants, ranging from 2,500 to 8,000 inhabitants. Every Metropolitan Area or Urbanized Area in the United States is completely divided into tracts. Because the primary concern in defining tracts is the population, the land area of tracts varies widely. The boundaries are established by local committees, following guidelines set by the Census Bureau.

${ }^{2}$ Zones were selected on the basis of their ability to; spur economic opportunity by creating jobs, attracting private partnerships, and training residents for new job opportunities; promote community development through a long-term economic development strategy; establish community-based partnerships; and develop a plan for responding to community needs by integrating economic, physical, human, and other strategies. (CRS, 2002)

${ }^{3}$ Social Service Block Grants can be used for a variety of services including: day care for children, employment services, counseling, legal services, transportation, education, and substance abuse recovery. These funds were given at the start of the program in 1995 and were not renewed.
} 
Employees that can be claimed for the EZ wage credit only need to be living in designated census tracts and be performing most of their work within the EZ (IRS, 2004). The EZ wage credit can be claimed for an employee only if the employee has worked for the employer claiming the credit for at least 90 days. There is, however, no upper bound on the tenure of an employee. There is also no requirement that the employee must be a new hire. The amount of the credit is $20 \%$ of the first $\$ 15,000$ in wages paid to a qualified employee, for a maximum credit of $\$ 3,000$ per employee (not indexed for inflation).

The most comprehensive evaluation of the EZ program as a whole was done by the Department of Housing and Urban Development (HUD) as part of an interim assessment of the program in 2001 (HUD, 2001). HUD (2001) estimates that 11 percent of firms surveyed in the urban EZs in the year 2000 reported using the wage credit; however HUD does not attempt to link these employees to actual tax credit claims. Other evaluations of the federal EZ program include Busso and Kline (2008), Hanson (2008), and Krupka and Noonan (2009). ${ }^{4}$ In general, these papers find the labor market effects of the EZ program to be mixed depending on the identification strategy used, but find substantial gains in the housing market.

The GAO (1999) examined the employer's decision to participate in all of the EZ tax benefits, including the EZ wage credit. They show that only 10 percent of employers used at least one of the tax benefits available and only 6 percent claimed the wage credit. In a follow up study, the GAO (2004) estimates the number of corporate tax returns that claim the EZ wage credit, but does not determine how many of these returns were eligible for the credit. Bershadker and Brashares (2004) characterize the types of taxpayers that claimed employees using the wage

\footnotetext{
${ }^{4}$ For studies that evaluate state zone-based programs see Papke (1994), Boarnet and Bogart (1996), Faulk (2002), and Couch et al. (2005).
} 
tax credit and estimate at least 4,600 workers were claimed under the EZ wage credit by corporations.

Most studies of wage tax credit use focus on the employee-based Earned Income Tax Credit (EITC), the largest wage subsidy program run by the federal government. ${ }^{5}$ What little we do know about the use of employer-based credits is about programs that target employees based on their personal characteristics, and participation in these programs is low compared to EITC estimates. Bishop and Kang (1991) estimate that only about 10 percent of employees eligible for the now expired Targeted Jobs Tax Credit (TJTC) were actually claimed. Katz (1998) estimates similar use rates for the TJTC, finding that only 9 percent of the eligible population was hired under the credit.

In the current federal tax system, the Welfare to Work (WtW) and Work Opportunity Tax Credit (WOTC) subsidize employers of certain types of workers (ex-felons, long term welfare cases, disadvantaged youth). Hamersma (2003) estimates the WOTC participation rate to be between 0.2 and 3.3 percent for the potentially eligible population receiving food stamps and between 0.3 and 16.6 percent conditional on the population that is new hires. She also estimates the participation rate for a sample of welfare recipients eligible for either the WOTC or the WtW to be between 3.7 and 5.7, and between 9.3 and 32.4 percent for new hires in the programs.

\section{Demographic and Economic Characteristics of the Zones}

The most recent data on Empowerment Zone residents is available from the 2000 census. ${ }^{6}$ As shown in Table 1, residents of urban EZs are younger, have less education and these

\footnotetext{
${ }^{5}$ See Dickert-Conlin et al. (2005) for a recent review on the use of employer and employee based tax credits available to low income individuals.

${ }^{6}$ The boundaries of each zone, however, are defined by 1990 census tracts, which do not always have a one-to-one mapping to year 2000 tracts. By matching census areas I am able to maintain 94\% of the original land area for all zones. Most of the lost land area loss comes from a single tract in the rural Mississippi EZ that is relatively unimportant for finding a national population total because that particular tract has a population of only 774, less than $.0001 \%$ of the national EZ total. The other major unaccounted for land area loss comes from the rural Rio
} 
areas have a larger percentage of non-white residents (the lone exception being the Detroit EZ) than their respective surrounding cities.

Unemployment rates in the EZs are in all cases at least twenty percent higher than the surrounding city. New York City has more than double the unemployment rate of the surrounding city. Atlanta, Baltimore, and Philadelphia all have at least a fifty percent higher unemployment rate than the surrounding city. The smallest gap in unemployment rates between the EZ and the surrounding city is in the D.C Enterprise Community where residents have about a thirteen percent unemployment rate. The Atlanta EZ has the highest unemployment rate, more than 25 percent. Correspondingly, employment rates are lower in EZs than the surrounding cities; no EZ has an employment rate that is more than ninety percent of the surrounding city employment rate.

The poorest EZs are Atlanta and Philadelphia, where annual per capita income was a bit over $\$ 9,000$ in 1999 . The D.C Enterprise Zone has the highest per-capita income at just over $\$ 20,000$, which is still only about 70 percent of the surrounding city per-capita income. Detroit has the smallest gap in per-capita income, where city residents make about \$2,000 more per year than zone residents. The percentage of EZ residents with annual income below the poverty line is between thirty and ninety percent higher than in the surrounding city in all EZs.

Rural EZs are also characterized by a population that is less educated than similar areas within those states, and have higher unemployment rates and lower income per capita. Summary statistics comparing rural EZs to Counties with a population density of less than 200 persons per square mile in each state are given in Table 2.

Grande Valley Texas EZ, where I lose 5,400 residents, less than .01\% of the national EZ population. I am able to match $99.6 \%$ of the original land area for all EZ tracts besides the two mentioned. Details about how census tracts were matched and a list of what tracts are included in this analysis are available from the author upon request. 


\section{National Use Estimates}

The employee use rate, as opposed to the filing rate of firms, quantifies how effective the credit is at reaching zone residents. The major obstacle to measuring use of the credit in each EZ is matching data. The IRS does not require employee certification, nor do they require an employer to specify which zone their employees are working in, making it difficult to determine the exact number of employees claimed under the EZ wage credit. The eligible population is determined by residence and employment in small geographic areas, accurate data on these populations is only available through the Census.

IRS form 8844 requires employers claiming the EZ wage credit to report the total dollar amount of wages paid against which a credit is claimed, but does not require the number of employees for whom the credit is being claimed to be reported. ${ }^{7}$ I estimate the minimum number of employees claimed by dividing the total dollar amount of credits claimed by the maximum credit per employee (set by statute at $\$ 3,000$ ).

I estimate the maximum number of employees claimed using the rules for claiming the credit. To claim the EZ wage credit the IRS requires an employee to have worked for a minimum of 90 calendar days; I assume that for a 90 calendar day employment period, a parttime employee works 5/7 of the days, 4 hours per day for a total of 257 hours. I use the federal minimum wage, and multiply by the minimum hours worked to get a minimum total wage bill. I

\footnotetext{
${ }^{7}$ IRS reporting of the credit dollars is broken down into a "tentative" amount and an actual amount claimed. The "tentative" amount is the amount employers claimed for the year, the actual amount is what was used to offset tax liabilities (other tax incentives for the EZs are not included in the dollar amount reported). The tentative amount represents the credits for an employee who worked for the employer in that year which can be carried over to offset future tax liability. I use the tentative dollars reported to create participation estimates in this paper. The GAO (2004) reports the actual amount of claims used to offset tax liability in a given year, which cannot be used to create reliable estimates of the number of employees claimed in a given year because this amount does not include credits that are carried forward.
} 
use the minimum total wage bill and the EZ credit rate of $20 \%$ to estimate a minimum credit claimed per employee of about \$264.

I assume that an employer claiming the credit draws the amount claimed per employee from a uniform distribution between the maximum and minimum credit per employee amounts. Using this assumption I derive an estimate of the number of employees claimed for all years which the credit is available (shown in Table 3); however I am only able to estimate a use rate for 1999 when Census data on the eligible population is available. ${ }^{8}$

Because few restrictions exist in claiming zone residents for the tax credit, it is necessary to consider most of the population living in EZ areas for the denominator of the use rate. I use three different denominators to estimate use rates: the working age population; the employed population; and the employed population likely working within the EZ. These estimates implicitly assume that employers claiming the credit are doing so for eligible employees only.

The working age population use rate shows how many of the potentially eligible have been claimed under the credit and is useful for measuring the market penetration of the credit. The employed use rate shows how many of the potentially eligible are being claimed, and is useful for interpreting employers' propensity to claim the credit. The percentage of the employed population working in the EZ that is claimed gives a more accurate estimate of the employer's propensity to claim the credit. Using census tract level data for each EZ, I estimate rates based on the working age population (age 16-65) and all employed zone residents. Table 4 shows this population data combined for all EZs.

\footnotetext{
${ }^{8}$ The ideal numerator in a use rate would be the actual number of zone employees claimed on each tax return. IRS form 8844 however, does not include this question. The IRS also does not require the employer to report the zone where employees are living and working in, so it is not possible to study the use of the credit across different EZs.
} 
The proportion of the working age population that is claimed shows how well the targeted population is reached. Although some of this population is likely to be unable to work, and therefore could not be claimed, this rate gives the most accurate measure of how well the target population is being reached by the EZ wage credit. Looking at the proportion of residents of the EZs who are employed shows the extent to which employers are claiming the credit for eligible workers.

The minimum and estimated use rates for the employed and working age populations are shown in Table 5. At least 3.5 percent of the working age population is claimed for the EZ wage tax credit, and using the uniform distribution assumption I estimate that about 6.4 percent is actually claimed. The lower bound measure suggests that the credit is somewhat more effective at reaching the target market than WOTC and WtW tax credits that have a lower bound on participation of about .2 percent of the target population. The uniform distribution estimate of the working age population utilization suggests that the EZ credit is reaching around the same percentage of the targeted group as credits with a categorical requirement.

At least 6.6 percent of the employed population is claimed for the EZ wage tax credit, and using the uniform distribution assumption I estimate that about 12.1 percent is claimed. The lower bound measure of the propensity for firms to claim the credit on eligible employees is slightly lower than the lower bound estimates in the literature for categorically targeted credits. The uniform distribution estimate, however, shows that firms use the EZ credit more than the TJTC, and is within the distribution of use estimates for the WOTC and WtW credits.

The standard measures of employment offered by the Census pose a problem for measuring use of the EZ wage tax credit because they do not separate those who are employed within the 
zone (a legal requirement of claiming the credit) and outside of the zone. ${ }^{9}$ To get a better idea of how many of the employed EZ residents actually work within the zones, I look again at the 2000 Census which asks those surveyed to estimate their travel time to work each day. This data is available at the tract level, and offers insight as to how many employed zone residents actually work within the zone.

Table 6 shows the travel time to work as a percentage of the employed population in the census tracts that make up each EZ, clearly there are many residents living in the EZs who have a travel time to work that would likely take them beyond the boundaries of a small urban area (EZs are between 4 and 28 square miles). Narrowing down the employed population to exclude employees who are likely to be employed outside of the zone gives a more clear idea of how employers are responding to the credit. If I count only those who are employed and have less than a 30 minute commute in an urban zone (leaving 100\% of rural employees) the use rate estimate among the employed is dramatically increased to 24.2 percent and at least 13.1 percent of the eligible employees.

\section{Why Are Utilization Rates Similar to Other Credits?}

Use rates for the EZ wage tax credit among the eligible population are similar to those estimated for other employer-claimed wage credits such as the Welfare to Work (WtW) and Work Opportunity (WOTC) tax credits. Other credits have categorical requirements on what type of individuals can be hired (such as welfare cases, ex-convicts, and economically disadvantaged youth), a strict minimum hours worked threshold, and mandatory certification requirements for employees claimed. With the added restrictions on other credits, it seems

\footnotetext{
${ }^{9}$ Also note that the program does not require employees to be living in the zone at the time the EZs were designated so that the employees that are claimed may have arrived after the start of the program. Given that the program is targeted to a particular place, rather than a set of individuals that share some characteristic, this may or may not be a desirable outcome of the program.
} 
reasonable that the EZ wage tax credit should have a higher use rate than these credits; however, the lower bound and preferred estimates presented here show that EZ wage credit use is within the range of estimates for WOTC and WtW participation by eligible employees estimated by Hamersma (2003). To think about why this is the case, it is helpful to think about the EZ wage tax credit in terms of costs, benefits, and constraints on both employees and employers.

The benefits of the credit are straightforward, up to a \$3,000 reduction in tax liability or 20 percent of the first $\$ 15,000$ in wages paid to an eligible employee. The amount of this benefit is not indexed for inflation, however, so the real value has declined substantially since the credit began in 1995. Factoring for inflation, the original \$3,000 credit created in 1993 is worth only $\$ 2,150.30$ in $2006 .{ }^{10}$ The real decline in value of the credit, especially in urban areas where wages grow quickly makes it a less attractive program for employers to participate in.

The HUD (2001) assessment points out that a potentially large cost to firms is that EZ areas may not be attractive locations to operate in relative to other areas of the city. The EZs were chosen because of their lack of economic opportunity to begin with, so there may simply not be enough firms willing to locate within the zones for a large proportion of residents to be claimed. The HUD assessment (2001) provides some evidence that firms operating within the zone have concerns about the surrounding area, 38 percent say that they are concerned about crime and safety in the EZ. However, evidence from the HUD assessment also suggests that most zone firms believe it to be a decent place to do business, 55 percent report that the EZ is a very good or somewhat good place to do business, and only 21 percent report the EZ to be a somewhat bad or very bad place to do business. ${ }^{11}$

\footnotetext{
${ }^{10}$ Authors calculations using CPI inflator at http://www.bls.gov/cpi/home.htm

${ }^{11}$ Note that this cannot explain the failure of eligible employers to claim eligible employees under the credit. Employers location preferences may, however, explain why so few of the working age population are claimed.
} 
The HUD (2001) assessment also points out that a constraint on use of the EZ wage credit is information. Employers in zones may not be aware that the credit exists, and if they are aware may not know how to file for it. The GAO (1997) surveyed employers operating in the original EZs and questioned them about their knowledge of the credit. Of those employers who did not claim the EZ wage credit, forty percent said they had no knowledge of the credit. An additional 8 percent reported it was too complicated to file for. The HUD assessment in 2000 found that 53 percent of firms surveyed knew about the EZ wage credit, however no reasons were given for not using the credit.

One reason often given for low use rates in employer-claimed wage credit programs is that they cause stigma for employees who do not want to be identified as needy or part of a group that receives a wage tax credit (for a theoretical background see Dickert-Conlin and Holtz-Eakin, 2000). Stigma can act to decrease the labor supply of the eligible population by imposing additional costs to being claimed for employer-based wage credits. The low use rates that I find for the EZ wage credit in this paper cannot be explained by employee stigma because the credit does not require an employee to be certified; in fact the employee may never even know that the employer is claiming the EZ wage credit.

Claiming the EZ wage tax credit also involves some fixed cost in learning about and filing for the credit, and employers will not claim it unless the benefit at least equals those costs. With high fixed costs, the cost per employee will be lower for large employers who claim more employees. This suggests that the credit is more likely to be claimed by employers who have more employees, which is what the evidence shows. HUD (2001) finds that 62 percent of firms in EZ areas with 250 or more employees use the EZ wage credit; this is compared to only 11 percent of firms of all sizes. Use of the credit declines to 51 percent for firms with 50 to 249 
employees, 19 percent for firms with 10 to 48 employees, and bottoms out at 5 percent for firms with between zero and nine employees.

\section{Conclusion}

Estimates presented in this paper show that at least 3.5\% of the population eligible for the EZ wage tax credit was claimed. Measures of the percent of eligible workers claimed, as well as the percent of those actually employed show that use of the EZ wage credit is similar to other employer-claimed wage credits, despite differences in the programs. It is not clear why use rates for the EZ wage credit are not higher given that the program should not cause stigma and the eligible population is potentially more diverse than that of other employer claimed wage credits, however lack of knowledge by employers and fixed costs associated with filing for the credit seem to be likely causes.

This paper takes a step toward evaluating the EZ program; however an evaluation cannot be done by looking at use of the wage tax credit alone. The ever-expanding role that geographically targeted wage credits (and tax incentives in general) play in policy-making begs a more complete evaluation of the EZ program as a whole. Because the zone targeting mechanism is broad it would also be interesting to know if the EZ is inducing new hiring of residents or merely a windfall to employers who have been operating in the zone all along. A complete evaluation of the program would also check for potential externalities that could be created on neighboring districts, and take a closer look at the possibility of fraudulent claims of the tax credits. 


\section{References}

Bershadker, Andrew, and Brashares, Edith, (2004). Use of the Federal Empowerment Zone Employment Credit for Tax Year 1997: Who Claims What? Statistics of Income, 23 (4), 171186.

Bishop, John, and Suk Kang, (1991). Applying for Entitlements: Employers and the Targeted Jobs Tax Credit. Journal of Policy Analysis and Management, 10(1), 24-45.

Boarnet, Marlon and William Bogart (1996). Enterprise Zones and Employment: Evidence from New Jersey. Journal of Urban Economics, 40, 198-215.

Busso, Matias and Patrick Kline (2008). Do Local Economic Development Programs Work? Evidence from the Federal Empowerment Zone Program. Cowles Foundation Discussion Paper 29 No. 1638; Yale Economics Department Working Paper No. 36.

Couch, John, Keith E Atkinson and Lewis H Smith (2005). The Impact of Enterprise Zones on Job Creation in Mississippi. Contemporary Economic Policy, 23(2), 255-260.

Dickert-Conlin, Stacy, and Douglas Holtz-Eakin (2000). Employee-Based versus EmployerBased Subsidies to Low-Wage Workers: A Public Finance Perspective. In Finding Jobs: Work and Welfare Reform, (David Card and Rebecca Blank), 262-95. New York: Russell Sage Foundation, 2000.

Dickert-Conlin, Stacy, Katie Fitzpatrick and Andrew Hanson (2005). Utilization of Income Tax Credits by Low-Income Individuals. National Tax Journal, 58(4), 743-786.

Faulk, Dagney (2002). Do State Economic Development Incentives Create Jobs? An Analysis of State Employment Tax Credits. National Tax Journal, 55(2), 263-280.

Hamersma, Sarah (2003). The Work Opportunity and Welfare- to-Work Tax Credits: Participation Rates Among Eligible Workers. National Tax Journal, 56(4), 725-38.

Hanson, Andrew (2008) "Poverty Reduction and Local Employment Effects of GeographicallyTargeted Tax Incentives and Grants: An Instrumental Variables Approach.” Urban and Regional Analysis Group Working Paper No. 08-10, Georgia State University, Andrew Young School of Policy Studies.

Internal Revenue Service. Department of the Treasury. Internal Revenue Bulletin No. 1998-47. November 23, 1998.

Internal Revenue Service. Department of the Treasury. Publication 954: Tax Incentives for Distressed Communities. Washington, D.C., 2004. http://www.irs.gov/pub/irs-pdf/p954.pdf.

Internal Revenue Service. Department of the Treasury. "Empowerment Zone and Renewal Community Employment Credit, Form 9944.” Washington, D.C, 2005. 
Katz, Lawrence F (1998). Wage Subsidies for the Disadvantaged. In Generating Jobs, (Richard Freeman and Peter Gottschalk), 21-53. New York: Russell Sage Foundation.

Krupka, Douglas and Douglas Noonan (2009). Empowerment Zones, Neighborhood Change, and Owner Occupied Housing. Journal of Regional Science and Urban Economics, 39(4), 386396.

Papke, Leslie (1994). Tax policy and urban development: Evidence from the Indiana enterprise zone program. Journal of Public Economics, 54(1), 37-49.

U.S Congressional Research Service. Empowerment Zone/Enterprise Communities Program: Overview of Rounds I, II, and III. Washington D.C. October 22, 2002

U.S Department of Housing and Urban Development. Interim Assessment of the Empowerment Zones and Enterprise Communities Program: A Progress Report. Washington, D.C, November, 2001.

U.S. Department of Housing and Urban Development. "Questions and Answers on Renewal Community and Empowerment Zone Tax Incentives” www.hud.gov/cr

U.S. General Accounting Office. “Community Development: Businesses’ Use of Empowerment Zone Tax Incentives.” Report to Congressional Requesters. GAO 99-253, Washington, D.C., September, 1999.

U.S. General Accounting Office. Community Development: Federal Revitalization Programs Are Being Implemented, but Data on the Use of Tax Benefits Are Limited. Report to Congressional Committees. GAO-04-306, Washington, D.C., March, 2004.

U.S. Office of Management and Budget (OMB). Analytical Perspectives, Budget of the United States Government, Fiscal Year 2007. Washington, D.C., 2006. 


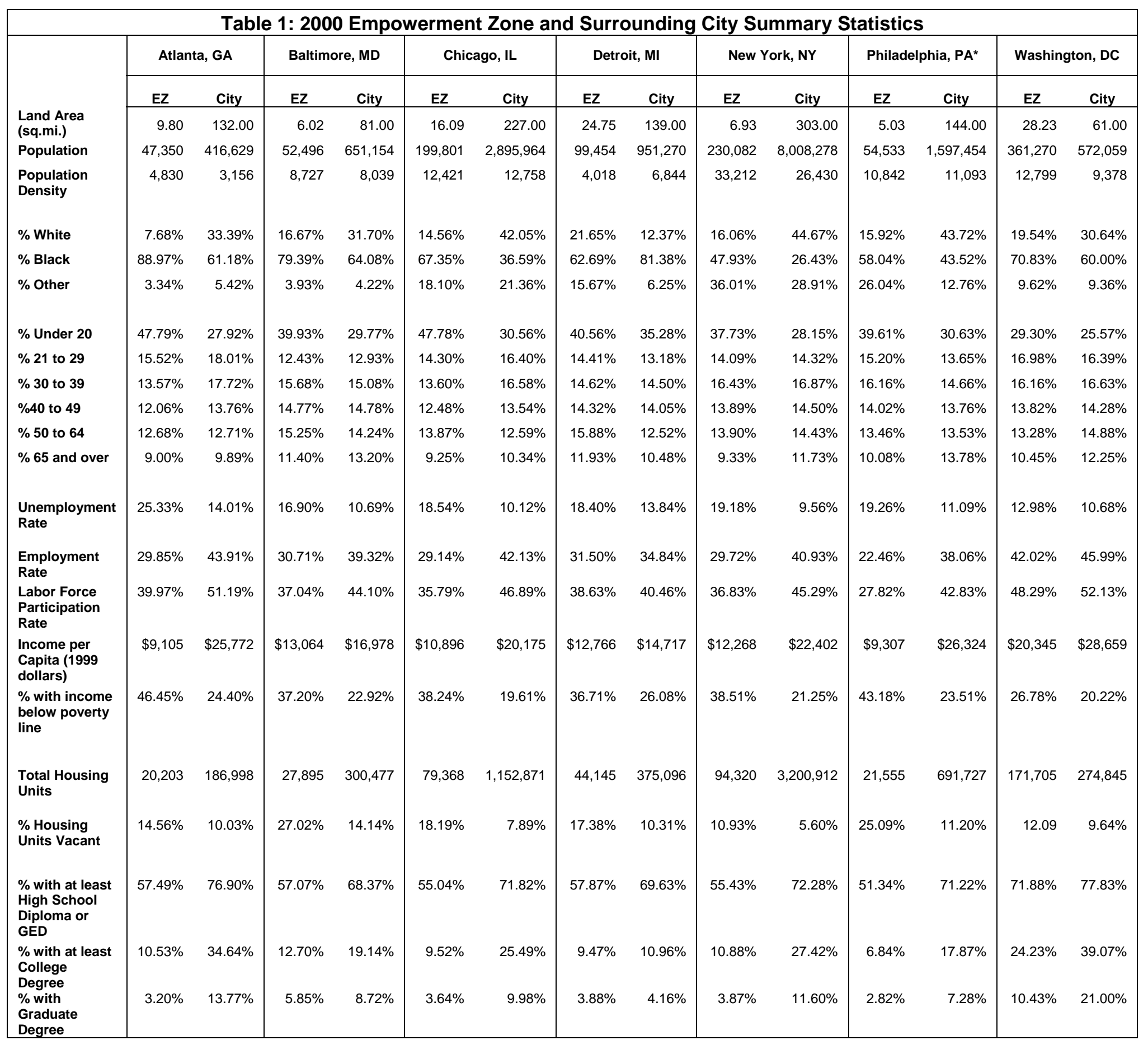

* The Philadelphia EZ also includes parts of Camden, NJ which are included in this analysis

Source: 2000 Census American Factfinder 


\begin{tabular}{|c|c|c|c|c|c|c|}
\hline \multirow[b]{3}{*}{$\begin{array}{l}\text { Land Area } \\
\text { (sq.mi.) }\end{array}$} & \multicolumn{2}{|r|}{ Rio TX } & \multicolumn{2}{|r|}{ MS Delta } & \multicolumn{2}{|c|}{ KY Highlands } \\
\hline & $2000 \mathrm{EZ}$ & $\begin{array}{c}2000 \text { State Rural } \\
\text { Area }^{*}\end{array}$ & $2000 \mathrm{EZ}$ & $\begin{array}{c}2000 \text { State Rural } \\
\text { Area }^{*}\end{array}$ & $2000 \mathrm{EZ}$ & $\begin{array}{c}2000 \text { State Rural } \\
\text { Area }^{*}\end{array}$ \\
\hline & 204.23 & 277491.20 & 893.20 & 47305.06 & 753.52 & 24573.39 \\
\hline Population & 31,235 & $7,884,183$ & 28,884 & $2,588,842$ & 30,478 & $2,527,730$ \\
\hline $\begin{array}{l}\text { Population } \\
\text { Density }\end{array}$ & 152.94 & 28.41 & 32.34 & 54.73 & 40.45 & 102.86 \\
\hline$\%$ White & $77.56 \%$ & $78.29 \%$ & $21.92 \%$ & $62.39 \%$ & $98.13 \%$ & $89.07 \%$ \\
\hline$\%$ Black & $0.38 \%$ & $9.15 \%$ & $75.51 \%$ & $35.69 \%$ & $0.36 \%$ & $9.70 \%$ \\
\hline$\%$ Other & $22.06 \%$ & $12.56 \%$ & $2.58 \%$ & $1.92 \%$ & $1.51 \%$ & $1.23 \%$ \\
\hline$\%$ Under 20 & $42.52 \%$ & $33.51 \%$ & $39.24 \%$ & $33.52 \%$ & $28.73 \%$ & $30.78 \%$ \\
\hline$\% 21$ to 29 & $13.72 \%$ & $11.50 \%$ & $13.03 \%$ & $12.27 \%$ & $11.48 \%$ & $14.58 \%$ \\
\hline$\% 30$ to 39 & $13.10 \%$ & $13.47 \%$ & $12.16 \%$ & $13.37 \%$ & $14.47 \%$ & $17.04 \%$ \\
\hline$\% 40$ to 49 & $11.87 \%$ & $13.73 \%$ & $13.17 \%$ & $13.89 \%$ & $14.85 \%$ & $12.78 \%$ \\
\hline$\% 50$ to 64 & $10.81 \%$ & $14.68 \%$ & $11.72 \%$ & $14.61 \%$ & $17.22 \%$ & $12.97 \%$ \\
\hline$\% 65$ and over & $7.98 \%$ & $13.12 \%$ & $10.68 \%$ & $12.34 \%$ & $13.25 \%$ & $11.86 \%$ \\
\hline $\begin{array}{l}\text { Unemployment } \\
\text { Rate }\end{array}$ & $15.78 \%$ & $5.99 \%$ & $17.80 \%$ & $7.80 \%$ & $7.76 \%$ & $6.86 \%$ \\
\hline $\begin{array}{l}\text { Employment } \\
\text { Rate }\end{array}$ & $28.27 \%$ & $41.78 \%$ & $31.86 \%$ & $40.18 \%$ & $37.44 \%$ & $44.08 \%$ \\
\hline $\begin{array}{l}\text { Labor Force } \\
\text { Participation } \\
\text { Rate }\end{array}$ & $33.56 \%$ & $45.28 \%$ & $38.76 \%$ & $44.01 \%$ & $40.59 \%$ & $47.32 \%$ \\
\hline $\begin{array}{l}\text { Income per } \\
\text { Capita (1999 } \\
\text { dollars) }\end{array}$ & $\$ 8,357$ & $\$ 16,749$ & $\$ 11,368$ & $\$ 15,040$ & $\$ 12,004$ & $\$ 16,642$ \\
\hline $\begin{array}{l}\% \text { with income } \\
\text { below poverty } \\
\text { line }\end{array}$ & $44.54 \%$ & $16.15 \%$ & $35.99 \%$ & $21.12 \%$ & $27.75 \%$ & $16.93 \%$ \\
\hline $\begin{array}{l}\text { Total Housing } \\
\text { Units }\end{array}$ & 9,698 & $3,171,038$ & 10,434 & $1,041,031$ & 15,161 & $1,029,262$ \\
\hline $\begin{array}{l}\text { \% Housing } \\
\text { Units Vacant }\end{array}$ & $16.45 \%$ & $13.37 \%$ & $9.53 \%$ & $10.40 \%$ & $18.97 \%$ & $7.63 \%$ \\
\hline $\begin{array}{l}\text { \% with at least } \\
\text { High School } \\
\text { Diploma or GED }\end{array}$ & $45.88 \%$ & $74.14 \%$ & $62.59 \%$ & $70.75 \%$ & $56.41 \%$ & $62.24 \%$ \\
\hline $\begin{array}{l}\text { \% with at least } \\
\text { College Degree }\end{array}$ & $6.75 \%$ & $16.79 \%$ & $11.70 \%$ & $15.35 \%$ & $6.75 \%$ & $14.93 \%$ \\
\hline $\begin{array}{l}\text { \% with } \\
\text { Graduate } \\
\text { Degree }\end{array}$ & $2.37 \%$ & $5.40 \%$ & $4.27 \%$ & $5.37 \%$ & $2.94 \%$ & $5.61 \%$ \\
\hline
\end{tabular}

For Comparison, Summary Statistics are given for all counties in the state with a population density less than 200 persons per square mile

Source: 2000 Census American Factfinder 
Table 3: Empowerment Zone Tax Credit Claims and Employee Estimates

\begin{tabular}{|c|c|c|c|c|}
\hline Year & $\begin{array}{l}\text { Total Credit } \\
\text { Dollars }\end{array}$ & $\begin{array}{l}\text { Minimum } \\
\text { Wage }\end{array}$ & $\begin{array}{c}\text { Minimum Employees } \\
\text { Claimed }\end{array}$ & $\begin{array}{l}\text { Estimate of Employees } \\
\text { Claimed }\end{array}$ \\
\hline 1995 & $\$ 20,173,000$ & $\$ 4.25$ & 6,724 & 12,536 \\
\hline 1996 & $\$ 33,395,000$ & $\$ 4.75$ & 11,132 & 20,588 \\
\hline 1997 & $\$ 59,741,000$ & $\$ 5.15$ & 19,914 & 36,598 \\
\hline 1998 & $\$ 64,135,000$ & $\$ 5.15$ & 21,378 & 39,290 \\
\hline 1999 & $\$ 75,650,000$ & $\$ 5.15$ & 25,217 & 46,344 \\
\hline 2000 & $\$ 98,727,000$ & $\$ 5.15$ & 32,909 & 60,481 \\
\hline
\end{tabular}

Source: Credit Dollars from personal correspondence with IRS, Minimum wage from BLS, Employees from author's calculations

Table 4: National EZ Population Data

\begin{tabular}{|c|c|}
\hline \multicolumn{2}{|c|}{ Zones Included: Atl, Chi, KY, Bal, Det, MS, NY, Phi, TX, DC } \\
\hline Total Population & $1,135,583$ \\
\hline Working Age Population (Age 16-65) & 720,376 \\
\hline Total Residents Employed & 381,688 \\
\hline
\end{tabular}

Source: Census 2000 American Fact Finder

Table 5: National Participation Rate for EZ Wage Credit (standard errors in parenthesis) Working Age Population (Age Total Residents 16-65) Employed

\begin{tabular}{|l|r|r|}
\hline Minimum Use Rate & $3.50 \%(0.005)$ & $6.61 \%(0.01)$ \\
\hline Estimated Use Rate & $6.43 \%(0.009)$ & $12.14 \%(0.03)$ \\
\hline
\end{tabular}

Source: Authors Calculations

Note: Standard Errors Calculated from Census estimates of denominator

Table 6: Employee Travel Time to Work (in minutes)

\begin{tabular}{|l|r|r|r|r|r|}
\multicolumn{1}{c}{} & \multicolumn{1}{c}{$<15^{*}$} & 15 to 30 & \multicolumn{1}{c}{30 to 45} & \multicolumn{1}{c}{45 to 60} & \multicolumn{1}{c|}{$60+$} \\
\hline Atlanta & $24.96 \%$ & $30.82 \%$ & $21.89 \%$ & $8.25 \%$ & $14.08 \%$ \\
\hline Chicago & $15.76 \%$ & $26.23 \%$ & $26.25 \%$ & $13.39 \%$ & $18.37 \%$ \\
\hline Kentucky Highlands & $32.65 \%$ & $34.43 \%$ & $16.29 \%$ & $6.69 \%$ & $9.94 \%$ \\
\hline Baltimore & $18.94 \%$ & $35.42 \%$ & $20.23 \%$ & $9.06 \%$ & $16.35 \%$ \\
\hline Detroit & $26.68 \%$ & $35.60 \%$ & $20.00 \%$ & $7.51 \%$ & $10.20 \%$ \\
\hline Mississippi Delta & $42.77 \%$ & $33.45 \%$ & $12.89 \%$ & $4.85 \%$ & $6.04 \%$ \\
\hline New York & $13.33 \%$ & $21.26 \%$ & $29.81 \%$ & $17.56 \%$ & $18.03 \%$ \\
\hline Philadelphia/Camden & $20.34 \%$ & $31.60 \%$ & $22.38 \%$ & $8.99 \%$ & $16.68 \%$ \\
\hline Rio Grande Texas & $37.31 \%$ & $34.00 \%$ & $20.32 \%$ & $3.49 \%$ & $4.87 \%$ \\
\hline Washington DC & $19.06 \%$ & $33.44 \%$ & $26.40 \%$ & $10.46 \%$ & $10.63 \%$ \\
\hline All EZ & $19.86 \%$ & $30.38 \%$ & $25.16 \%$ & $11.32 \%$ & $13.29 \%$ \\
\hline
\end{tabular}

* Also includes those who work at home

Source: 2000 Census American Fact Finder 